\title{
Natural Ways to Decompose Plastics
}

\author{
Vijayshree, Seema Chawla
}

\begin{abstract}
Science and technology has given various good things and their applications to us. But along with their benefit some goods are harmful too for both human being and our environment. Plastic is one of them, which has many commercial as well as daily uses. There are many advantages of it but one main drawback is that it's not degradable by nature. It can neither be degraded naturally nor synthetically. If we even try to degrade it chemically or physically, it would produce many harmful by products which are toxic in nature and pollute the environment as well. So, the only safe way is biodegradation. In recent discoveries many microbes are found to degrade different types of plastics biologically. We have tried for two sources of university premises the polluted soil of dumping site and the sewage effluent. And during the study we isolated two bacterial strains, which have removed some percentage of PET plastic in a bacterial broth media in its initial 24 hrs. The study is going on further. The aim of this paper is to spread awareness and create innovation to all young minds to find new ways to overcome from plastic pollution crisis of the mother Earth.
\end{abstract}

Index Terms - Biodegradation, Environmental Pollution, Microbial Strains, Plastics.

\section{INTRODUCTION}

Environmental pollution is a consequence of industrial processes and human activity. Among these plastics are of great concern due to their non-biodegradable properties which are frequently used in industrial processes and widely distributed in the environment. As we all know about wide spread uses of plastics. The plastic has many advantages like light weighted, strong, durable, corrosion resistant, reusable, non-reactive and inexpensive. But the only disadvantage makes it very dangerous for our environment i.e. it's not completely degradable by physical methods. The physical method for degradation of plastics includes land filling, incineration and reusing (recycling). [1]. These traditional methods and their byproducts are harmful for human health and earth's atmosphere. [2].

All types of plastic jars, containers and bottles are known as rigid packaging. These plastics are reused and recycled by non-formal chain of rag pickers and kabaadi wallahs or other scrap dealers. The companies are putting collaborative efforts to enhance recycling of rigid plastic material used packaging by reverting packaging back to the company. But the single use plastics like bags, candy wrappers, tobacco and pan masala sachets, soap wrappers and shampoo sachets are either too difficult or not lucrative enough to collect. These single use plastic wrappers are swallowed by animals everywhere on land or in marine and indirectly included into

Revised Version Manuscript Received on 10, September 2019.

Vijayshree, Department of Biomedical Engineering Deenbandhu raovijayshree@gmail.coml)

Seema Chawla, Department of Biomedical Engineering Deenbandhu Chhotu Ram University, Murthal, Sonipat, Haryana. (Email: seema.bme@dcrust.org) Chhotu Ram University, Murthal, Sonipat, Haryana.(Email:

our food chain systems. This can cause serious cancer to all the living beings. like mammary gland tumors found in animals too. [3]. A huge amount of plastic is present in the form of waste not only on the land but also found by the deep dive investigations under the sea water using the minisubmercible. [4].

Apart from all these harms of plastics the new era of science has found many ways to resolve these problems to degrade it fully producing no harmful by products. In recent discoveries many microbes are found to degrade different types of plastics biologically. Not only the microbes but there are also some other organisms that can degrade the plastic, i.e. wax worms, marine worms and mushroom. [20] [21] [22].

Even some fungal strains can also degrade the plastic at a faster rate. In further studies many other ways are found to degrade the plastics biologically, like in 2018 Korean scientists found a marine worm Marphysa sangunea can eat the plastic and release out 11,200 micro plastic particles.[21] Some scientists have discovered a mushroom which can degrade the plastics completely to an organic matter which can not only be consumed by the humans but also used for cleanup of landfills.[22]. On other studies found that a wax worm can also degrade plastic to an organic compound. [20]. In the same way we have also put small efforts to find out the plastic eating microbes in our surroundings

\section{ADVANTAGES OF BIODEGRADATION}

A.Big biodegradable solution for all types of plastics, to make the Earth plastic free

B.Can degrade a large amount of plastic waste and environment friendly solution.

C. Having no harmful byproducts.

The byproducts during plastic degradation like methane can be reutilized as energy source.

\section{MECHANISM OF BIODEGRADATION OF PLASTIC}

As all we know that some organic as well as inorganic materials are used in production of plastic. for example $\mathrm{C}, \mathrm{Si}$, $\mathrm{Cl}, \mathrm{O}_{2}$ etc.[5]. So, there are mainly two basic types of plastics.

1. Thermoplastics

2. Thermoset plastics [17][18].

Different discoveries show different ways of biodegradation of plastics. In Japan scientists have tested different bacterial strains from a bottle reprocessing plant in 2016 and they found bacterial strains of Ideonella sakaiensis. This works on secreting an enzyme i.e. a protein that speeds 
up the reaction. This bacterial strain can degrade and absorb the plasticwhich is used in manufacturing disposable bottles made up of polyethylene terephthalate (PET). [6].

After that many more researches have made many more researches in the same way.

In some cases where LDPE is degraded using bacteria due to their efficient production of hydrophobic enzyme which helped them to form biofilm that is required to be attached to the polymer surface.[7] [8].

Again in some studies it has been shown that the fungal strains were more faster than bacteria and make a conclusion that extracellular enzymes carried out the decaying process. [9] [10] [11].

\section{MATERIALS AND METHODS}

From the above discussion we come to know that each microbe acts in a different way for degradation of different plastics. Here is the list of some microbes to tell how efficient they are for a particular plastic.

Table I : Different plastics and degrading microbes.

\begin{tabular}{|c|c|c|}
\hline $\begin{array}{c}\text { Sr.No } \\
.\end{array}$ & Plastic names & $\begin{array}{l}\text { Degrading microbes (B- } \\
\text { Bacterial, F- Fungal) }\end{array}$ \\
\hline 1 & $\begin{array}{c}\text { PET } \\
\text { Polyethyelene } \\
\text { terepathelate }\end{array}$ & $\begin{array}{l}\text { B-Ideonella-sakaiensis. } \\
{[6][12] .}\end{array}$ \\
\hline 2 & $\begin{array}{l}\text { Low Density } \\
\text { Polyethelene }\end{array}$ & $\begin{array}{l}\text { B-Pseudomonas spp.,, Bacillu } \\
\text { ssp., Staphylococcus spp. } \\
\text { polythn, asmi ,lpde } \\
\text { F-Aspergillus, } \\
\text { Penicillium[13][16][17][18] }\end{array}$ \\
\hline 3 & $\begin{array}{l}\text { Poly (beta- } \\
\text { poprolactone) }\end{array}$ & $\begin{array}{c}\text { F-Acidovorax and } \\
\text { Virovorax paradoxus } \\
\text { spp. }[23]\end{array}$ \\
\hline 4 & Poly lactic acid & $\begin{array}{l}\text { B-Amycolatopsis spp., } \\
\text { Proteinase K. }[13,24]\end{array}$ \\
\hline 5 & $\begin{array}{c}\text { Poly-3-hydroxy } \\
\text { butyrate }\end{array}$ & $\begin{array}{l}\text { B-Pseudomonas spp. and } \\
\text { Comamonas spp.[19] }\end{array}$ \\
\hline 6 & $\begin{array}{l}\text { Polyethylene } \\
\text { adipate }\end{array}$ & $\begin{array}{l}\text { B-Acromobactor and } \\
\text { F-candida spp }\end{array}$ \\
\hline
\end{tabular}

\section{PROCEDURE OF ISOLATION OF MICROBIAL STRAINS}

In the present study, bacterial species were used which is isolated from the soil \& sewage sample by serial dilution and pure plating method. These were isolated from the plastic contaminated soil in university premise. The strain was maintained in the nutrient medium and appropriate proportions. First of all we have collected the soil and sewage samples . These samples were collected from university premises.

The each sample was properly homogenized with $5 \mathrm{ml}$ of distilled water. Now, we have taken $1 \mathrm{ml}$ of the prepared sample and serially diluted it ten times with ten test tubes having $9 \mathrm{ml}$ distilled water in each for each sample. These all dilutions were spreaded uniformly onto Petri plates prepared with agar growth media as $1 \mathrm{ml} /$ plate and different plates for different dilution were prepaired.

\section{A. Inoculation Of Samples In Petri Dishes \& Incubation}

All the sterilized nutrient agar media is then distributed in the sterilized Petri dishes as per standard under sterilized conditions and stand for solidification of media in a laminar flow. Now, all the dilutions were spreaded on the surface uniformly on the Petri plates. These plates were incubated for 72 hours at $32^{\circ} \mathrm{C}$ in an incubator. A loopful of cells from the reserve culture was inoculated into $50 \mathrm{ml}$ disinfected nutrient broth in triple sets and incubated at $32^{\circ} \mathrm{C}$ for $24 \mathrm{hrs}$. with shaking. After incubation period cells were harvested .. In this procedure the serial dilution technique was used to dilute both samples. o.1 $\mathrm{ml}$ sample from each dilution were inoculated on the freshly made nutrient agar petri dishes and incubated at $32^{\circ} \mathrm{C}$ for $24 \mathrm{hrs}$.

\section{B. Pure culturing of bacterial strains}

After 72 hrs. we obtained proper growth of all the bacterial strains. These bacterial strains were then again transferred to fresh agar media petriplates for further purification of the strain as shown in fig. $1 \mathrm{a} \& 1 \mathrm{~b}$. Out of all the species only 2 species were tolerant to the plastic wastes as shown in fig. $2 \mathrm{a}$ $\& 2$ b. These species were cultured in the Nutrient Broth (NB) media in conical flasks/ sterile plastic tubes after streaking shown in fig 3.

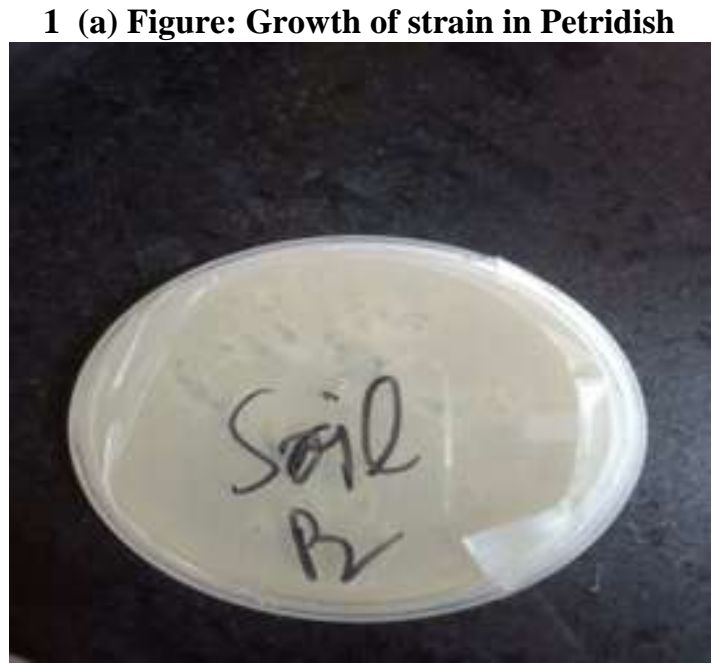

1 (b) Figure: Plastic dosing in Petridish.

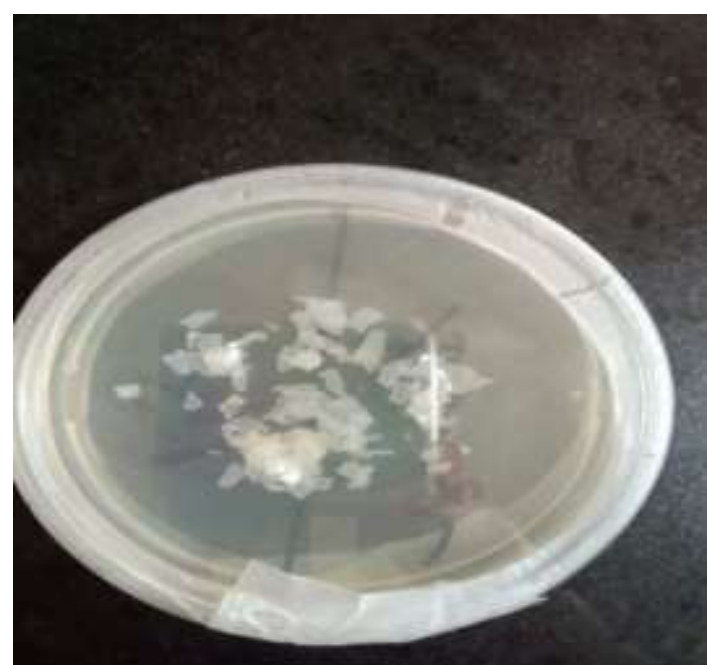

(a) Figure: Pure culturing of bacteria (Soil). 


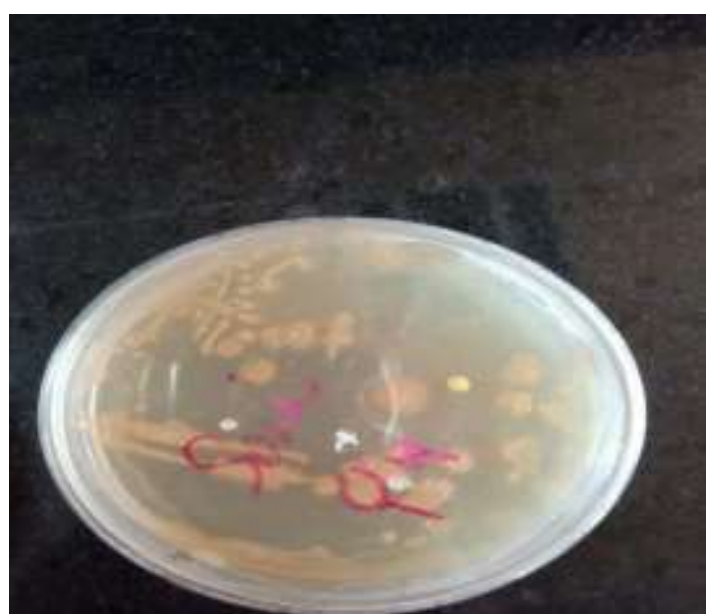

2 (b) Figure: Pure culturing of bacteria (Sewage).

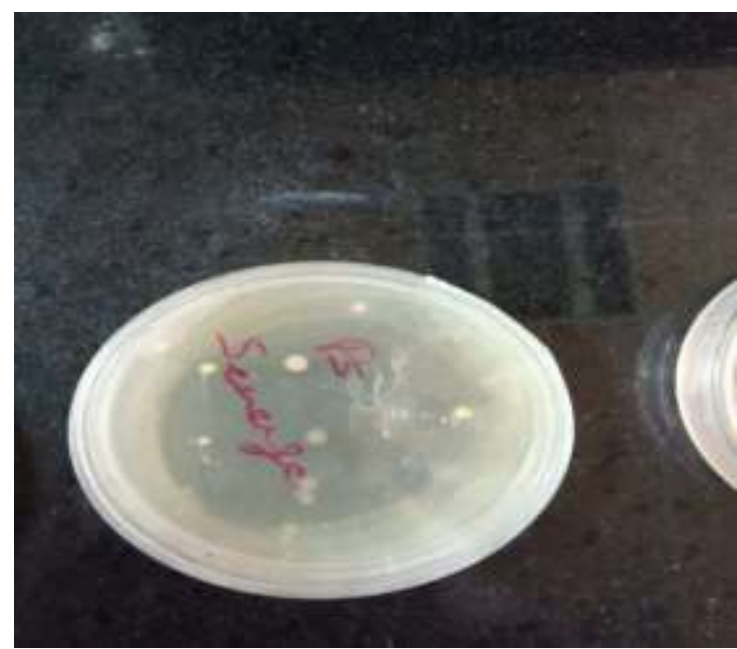

3 Figure : Bacterial strain tolerance testing.

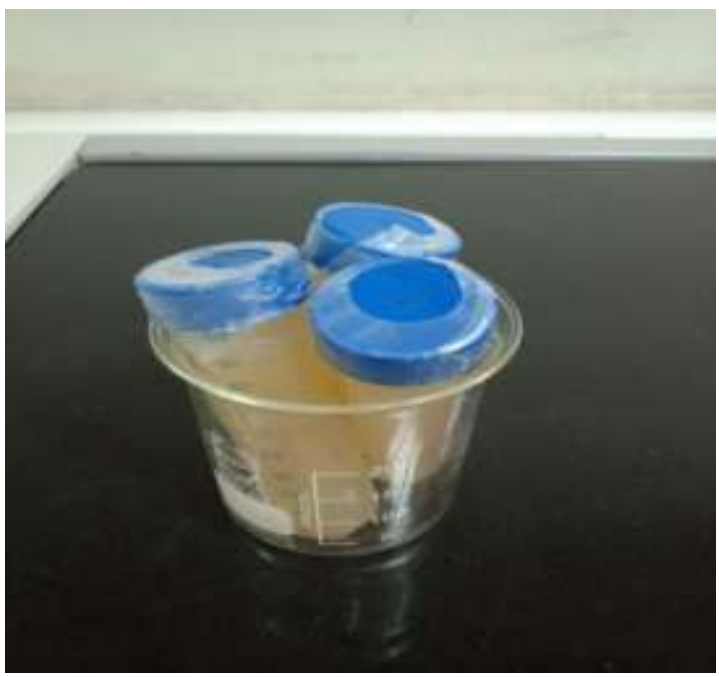

\section{RESULTS}

In the present study of isolation the soil bacterial strain were yellow and off white in color and the sewage bacterial strain was pure white in color. The yellow strain has shown consumption of $38 \mathrm{mg}$ out of $500 \mathrm{mg}$ in 24 hours while the pure white strain shown $40 \mathrm{mg}$ of consumption out of $500 \mathrm{mg}$ of plastic waste strips. The percentage reduction was 7.6 and 8.0 respectively for both yellow and white strains. Isolation of effective candidates for biodegradation was done based on the recorded biodegradation outcomes.
Table II: Percentage reduction of plastic eating bacterial strain

\begin{tabular}{|c|c|c|c|}
\hline Sr.No. & Bacterial strain & $\begin{array}{c}\text { Total consumption } \\
\text { out of } 500 \mathrm{mg}\end{array}$ & $\begin{array}{c}\text { Percentage } \\
\text { reduction }\end{array}$ \\
\hline 1 & Yellow bacterial strain(soil) & $38 \mathrm{mg}$ & $7.6 \%$ \\
\hline 2 & $\begin{array}{c}\text { Pure white bacterial } \\
\text { strain(sewage) }\end{array}$ & $40 \mathrm{mg}$ & $8.0 \%$ \\
\hline
\end{tabular}

\section{CONCLUSIONS}

Plastics are very complex materials which are everywhere in the present era. Once they get into the environment as waste, it takes decades or centuries to decompose. It's all because of plastic is chemically inert and immune to biological or enzymatic reactions Discoveries are made to solve this problem by microbial communities which are exposed to PET. Some new bacterial strains can be invented to decompose the plastics, this may be used for remarkable consumption of plastics which in turn will help to reduce the plastic pollution.

There are many good prospective in the field of biodegradation of plastic pollution, by not only isolating microbes but also by using genetic engineering to generate the more and more efficient enzymes that can degrade at more faster rates. And also by inventions of different animals too that can more effectively remove toxins and plastics.

\section{REFERENCES}

1. Mario C., Plastic materials and environmental externalities: structural causes and corrective policy, Lethbridge Undergraduate Research Journal, 2008, 3(2).

2. Raziyafathima M., Praseetha P.K., Rimal Isaac R.S., Microbial Degradation of Plastic Waste: A Review.Journal of Pharmaceutical, Chemical and Biological Sciences, ISSN: 2348-7658, June 2016, 4(2), pp 231-242.

3. Mody A.S., Biodegradable plastics, Plastic packaging, 2000, 45, pp 89-91.

4. Fugikura K., Okutani S. and Maruyama T., Deep-sea Life-Biological observations using research submersibles, Tokai University Press, 2008, pp 57-80.

5. Adil F.L., Fariha H., Ziaullah S., Abdul H., Shah F. and AamerA.S., Optimization of culture conditions for the production of poly (3-hydroxybutyrate) depolymerase from newly isolated Aspergillus fumigates from soil Pakistan Journal of Botany., 2011, 43(2),pp 1361-1372.

6. Emily F., How plastic-eating bacteria actually work - a chemist explains, The conversation, April 2018.

7. Kershaw M.L. and Talbot N.J., Hydrophobins and repellents: Proteins with fundamental roles in fungal morphogenesis, Fungal. Genet. Biol.,(1998), 23,pp 18-33.

8. Seneviratne G., Tannakoon N.S., Weerasekara M.L.M.A.W. and Nandansena K.A., LDPE Biodegradation by a developed Penecillium Bacillus biofilm, Curr. Sci., (2006), 90, pp 2021.

9. Kim D.Y. and Rhee Y.H., Biodegradation of microbial and synthetic polyesters by fungi. Appl. Micro. Biotech., (2003), 61, pp 300-308.

10. Shah A.A., Hassan F., Hameed A. and Ahmed S, Biological degradation of plastics: a comprehensive 
review, Biotechnol. Adv., (2008), 26, pp 246-265.

11. Frazer A.C., O-methylation and other transformations of aromatic compounds by acetogenic bacteria In: Acetogenes . Drake HL (edi). Chapman \& Hall, New York. (1994).

12. Vona IA, Costana JR, Cantor HA, Roberts WJ. Manufacture of plastics. New York: Wiley, 1965, pp 141.

13. Noopur M., Sakshi S, Snnuradha N.S., Toxicity and biodegradation of plastics: A review, J Environ Dev, 2015, 9(3), pp 906-913.

14. Suman M. and Shamba C., A comparative study of commercially available plastic carry bag biodegradation by microorganisms isolated from hydrocarbon effluent enriched soil. Int J Curr Microbiol App Sci, 2014, 3(5),pp 318-325.

15. Swapna K. G., Sujoy P., Sumanta R., Study of microbes having potentiality for biodegradation of plastics. Environ Sci. and Pollution Research. 2013, pp 11356 - 013.

16. Jeevan K. S., Dev Raj J., Prakriti R. and Govinda B., Isolation and Identification of Low Density Polyethylene (LDPE) Degrading Bacillus spp. from a Soil of Landfill Site, Acta Scientific Microbiology, ISSN: 2581-3226,April 2019, 2(4),pp 30-34.

17. Divyalakshmi S1, Subhashini A, Screening and Isolation of Polyethylene Degrading Bacteria from Various Soil Environments, , ISSN: 2319-2399, Dec. 2016,10(12,4 ), pp 01-07.

18. Jyoti S., Dr. Gupta K.C., and Archana S., Isolation And Identification Of Low IOSR Journal of Environmental Science, Toxicology and Food Technology Density Polyethylene (Ldpe) Degrading Bacterial Strains From Polythene Polluted Sites Around Gwalior City (M.P.), Journal of Global Biosciences, ISSN 2320-1355, 2015, 4(8), pp. 3220-3228.

19. Dieter J., Ingrid K., Rahim Bahodjb H., Alexander S., Hans Günter S., Degradation of poly(3-hydroxybutyrate), PHB, by bacteria and purification of a novel PHB depolymerase from Comamonas sp., Journal of environment polymer degradation, 1993,1(1), pp 53-63.

20. https://www.nationalgeographic.com/news/2017/04/waxworms-eat-plastic-polyethylene-trash-pollution-cleanup/

21. https://www.hakaimagazine.com/news/marine-worms-ar e-eating-plastic-now/

22. http://yupthatexists.com/pestalotiopsis-microspora-plasti c-eating-mushroom/

23. https://www.sciencedirect.com/topics/agricultural-and-bi ological-sciences/acidovorax

24. https://doi.org/10.1111/j.1574-6968.2008.01109.x 